\title{
Qualification of the adaptive capacities of livestock farming systems
}

\begin{abstract}
Benoît Dedieu1
${ }^{1}$ Institut National de la Recherche Agronomique, INRA, UMR 1273 Métafort, site de Theix, F-63122 Saint Genès Champanelle, France.

ABSTRACT - This paper aims at exploring what is covered by «adapting to last » with a farming systems approach. Long term dynamics can be analysed as adaptive cycles, the system being permanently exposed to disturbances and shocks. Mobilizing the concept of resilience, we analyse the factors that differentiate the principles for long term action the livestock farmers have, principles which give consistency to the family - farms trajectories. With the concept of operational flexibilty, we qualify the sources of flexibility the livestock farmers maintain to cope with hazards. They are internal, related to the production process regulation properties, to the technical (adaptive or rigid) specifications, to the sales policies, or external related to the information and commercial networks. Understanding the production process regulation properties require livestock farming systems models (i.e. combining decisional and biological sub-systems) that can simulate how herd dynamics operate under fluctuant rules or productive parameters. It also require to evaluate the room for manoeuvre the work organization let to the farmer. All these aspects are illsutrated with on farm studies in herbivore systems (sheep, dairy, beef).
\end{abstract}

Key Words: adaptation, flexibility, livestock farming systems, resilience, room for manoeuvre, system regulations

\section{Qualification of the adaptive capacities of livestock farming systems}

RESUMO - Este artigo busca explorar "adaptações a mudanças" sob a ótica de sistemas de produção animal. Dinâmicas de longo prazo podem ser analisadas como ciclos adaptativos, sendo o sistema permanentemente exposto a distúrbios e choques. Utilizando o conceito de resiliência, analisam-se os fatores que diferenciam os princípios para ações de longo prazo tomadas por produtores rurais, princípios estes que dão consistência à família - trajetórias da propriedade rural. Com o conceito de flexibilidade operacional, qualificam-se as fontes de flexibilidade que os produtores mantêm para lidar com riscos. Eles são internos, relacionados a propriedades de regulação do processo produtivo, a especificações técnicas (adaptáveis ou rígidas), a políticas de vendas; ou externos, relacionados a redes de informação ou comercialização. A compreensão das propriedades de regulação do processo de produção exige modelos de sistemas de produção animal (i.e. por combinação de sub-sistemas de decisão e biológicos) que possam simular como a dinâmica do rebanho opera sob regras variáveis ou parâmetros produtivos. É necessário também avaliar o espaço para manobra da organização do trabalho deixado ao produtor. Todos esses aspectos são ilustrados com estudos em sistemas de pastagens (ovino, bovino de leite, bovino de corte).

Palavras-chave: adaptação, espaço para manobra, flexibilidade, regulação de sistemas, resiliência, sistemas de produção animal

\section{Introduction}

Research into livestock farming has always been guided by the search to improve the efficiency of the activity, in particular via the exploration of optimised solutions on gross margin or income criteria and the on-farm analysis of margins of technical progress towards these optimums. However the growing uncertainty that hangs over the livestock context suggests to more and more authors that they should give importance, in analysis and evaluation, to the adaptive capacity of livestock systems. By adaptive capacity, we mean the capacity to resist medium term uncertainties and adopt a dynamic, a movement that will enable them to survive in the long term (Mignon 1993, Dedieu et al. 2008a, Darnofer etal. 2008), whilst:

- Concrete data of what this distant future will be cannot be specified,

- The occurrence of sudden serious crises (health crises, financial collapse...) is more than probable without being "probabilisable", or measurable,

- The volatility of prices (products, inputs) and the general orientation of CAP reforms (fewer safety nets) make the livestock farming environment more unstable and weaken 'shock absorbers' against uncertainties.

- Climatic change gradually marks production conditions, with the occurrence of more frequent extreme climatic events. 
Criticisms of the productivist model reinforce the necessity for concern about a system's adaptive capacity. The control of factors that limit production via irrigation, the use of pesticides, elaborate health prevention etc. has negative effects on the environment that should now be avoided. The search for production models of higher environmental value is also, in livestock farming, the search for systems that can cope with variations, in particular climatic, rather than smoothing them over.

In this article, we aims at exploring what is covered by «adapting to last» with a livestock farming systems approach (Gibon \&Hermansen, 2006; Dedieu et al.; 2008a et b). In a first part, we specify the dynamic vision of livestock farming we are concerned with, with reference to the literature dealing with « resilience ». Then, in a second part, we illustrate the diversity of «paths » of long term action in situations of uncertainty via a synthesis of research operations carried out in France and South America. In a third part, we discuss the resistance of systems to variations, in particular of prices and climate, with reference to the management science concept of «flexibility ». Finally, we evoke the way in which the systemic approach and the notions of « regulation » and room for manoeuvre makes it possible to explore the «production process » flexibility.

\section{Livestock farms in dynamic}

What dynamic vision of livestock farming underlies research into animal husbandry? With the impression made by the technical and economic optimization approach, it is essentially a question of producing knowledge and models to optimize a given situation or to seek a new combination of activities and techniques coherent with a new context (new price ratio, CAP reforms, environmental regulation etc). In fact, the dynamic vision of livestock farming systems corresponds to a succession of transitions from state $i$ of the system towards state $i+1$, transitions justified by a change of context. .States $i$ and $i+1$ are, in the extreme majority of cases, considered as stable, as is their environment. Other ways of looking at long time and system transformations have seen the light of day: Lev \& Campbell (1987) for example underlined the danger of ignoring long term interactions in the search for more viable solutions for farmers and pointed out the challenge of maintaining flexibility in systems subjected to uncertainty. More recently, research in ecology ${ }^{1}$ considers that dynamising a system includes brutal shocks, which can call its very existence into question. The ecologists include these shocks in a whole collection of quasi permanent disturbances with which the system must deal. Holling (2001), interested in social-ecological systems, proposed a general framework of representation of these dynamics of the systems as an adaptive cycle (Figure 1).

The resilience ${ }^{2}$ of a system characterises the property of a system that lasts, i.e. which is capable of confronting disturbances at all stages of the cycle, including shocks. The main issue in this last case is to mobilise the right resources to reconfigure the system. Thus, for these authors, there is in itself no stable state or environment, but a continuous dynamic constituent of the view that can be taken of the system. At farm scale and taking inspiration directly from the context of Holling, Milestad et al. (2003) underline the necessity of taking into account the trajectories of the «family - farm-other activities » system to characterise the resilience they define as «the capacity to deal with internal and external changes, due to predictable causes (uncertainties) or unusual causes, the capacity to learn and adapt to uncertainties, the capacity to reorganise in the event of shocks ». Darnhofer et al. (2008) also considered that "rather than working the adaptation "from a stable state to another stable state 》 under the effect of drivers for change (PAC...), it is more a question of « developing an « evolutionary » approach

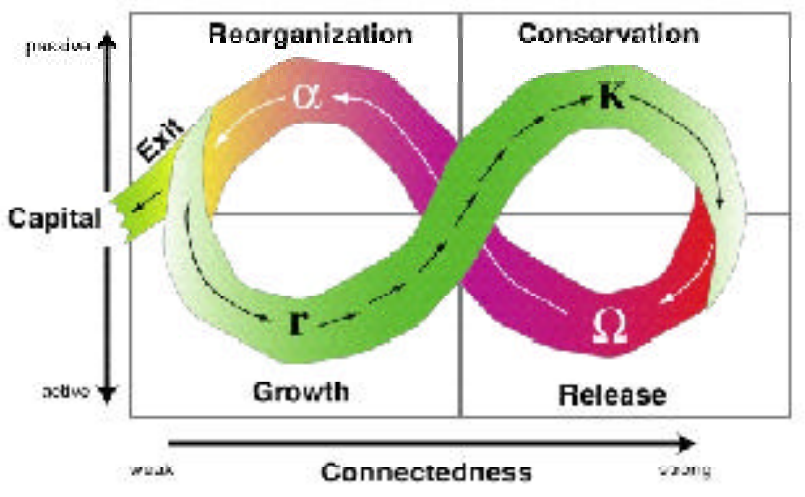

Figure 1 - The adaptive cycle of a social-ecological system (Holling, 2001).

The diagram has to be read as a large figure o russian mountains. $\mathrm{r}$ to K: a situation that changes little or slowly, subject to uncertainties. Learning allows a capacity for control and increasing mastery $\mathrm{K}$ to $\Omega$ : shock. Release of resources. $\Omega$ to $\alpha$ : mobilisation of potential (resources, capital) to reorganise the system. Exit (failure) or starting a new cycle.

\footnotetext{
${ }^{1}$ But also in other disciplines like psychology (Cyrulnick, 2001).

${ }^{2} \mathrm{~A}$ whole community of research interested in the management of natural areas can be found around this approach of the resilience of social-ecological systems www.resalliance.org.
} 
to the dynamics offarming systems considering resistance to variations, taking uncertainty into account and the capacity to re-design systems in the long term ».

Diversity of paths to last over the long term

The application of this theoretical framework makes it possible to question «action in a situation of uncertainty» (Lemery et al., 2005), in other words to produce knowledge of the action principles which mark system dynamics over the long term. We carried out several studies between 2002 and 2008 aimed at 1) identifying the diversity of paths (logics of action) taken by livestock farmers to last over the long term, 2) connecting these paths and the tensions exerted on the system operation at the time of the observation, and the sources of flexibility which make it possible to cope with them (cf following part). These studies concerned beef cattle farming in Burgundy (France), dairy farming in Ségala (Massif Central, France), and departing from a context of strong production support, cattle farming (meat - milk) in Uruguay ${ }^{3}$ (Table 1).

The studies carried out in France mobilized a multidisciplinary group bringing together animal scientists, management scientists and sociologists. Methodology was based on the approach of the trajectories of the farm - family - other activities system according to the framework proposed by Moulin et al. (2008), in which the analysis aims at delimiting, from statements from the farmers:

- phases of « coherence » associated with a set of principles for action, the system evolving under the effect of disturbances;

- phases of "disruption" associated with shocks (of all types) leading to reconfiguration of the system, and if necessary, new action principles.
Pooling data from the 3 studies (39 cases) underlines 4 registers advanced by farmers to explain and/or justify the events that mark their farm trajectory:

- configuration of the family-farm system, i.e. the options relative i) to size (with modalities « getting bigger to survive » or conversely « getting bigger is not for me: you loose the control"); ii) to a combination of activities (opposing diversification (« not all the eggs in one basket») and specialisation ( « the only way for being competent and efficient »); iii) to taking risks («never », « necessary », « only if controlled »)

- finances, namely the relation to being in debt (« never », « a necessary evil «), to savings (systematic or not), to the possibility of adjusting needs and family withdrawals in a difficult year.

- the operation of the technical system. 3 modalities could be identified: technical ambition is the key ( $«$ it is the guarantee for survival »); management ambition (« what matters is the optimisation of all the farm resources combining technical, economical, fiscal matters, including an efficient work »); keeping flexibility in the whole farm systems and/ or in the production process ( « keeping some in reserve », «never being short of resources »)

- Socio-technical networks(of information, exchanges and advice, enabling mastery of the downstream («you have to invest in producer organisations »).

All these registers do not play the same role in the differentiation of the paths over the long term, sample by sample. The registers of configuration of the family-farm system and of operation of the technical systemappear to have greater relative importance to differentiate the paths. Boxed text 1 presents the range of registers in 6 types of paths in the dairy cattle group of farms of Ségala. Boxed text 2 presents the 4 types identified in Uruguay.

Table 1 - Three studies on «action in a situation of uncertainty » in livestock farming

\begin{tabular}{|c|c|c|c|c|}
\hline & Number of farms & Year & Herd number & Publication \\
\hline Beef cattle in Burgundy $(F)$ & 14 & $2001-2004$ & $40-145$ cows & $\begin{array}{l}\text { Lemery et al. (2005) } \\
\text { Ingrand et al. (2007) }\end{array}$ \\
\hline Dairy cattlein Ségala (F) & 14 & $2006-2009$ & $17-55$ cows & Begon et al. (submitted) \\
\hline Cattle inUruguay & 11 & $2006-2007$ & $\begin{array}{l}8 \text { beef : } 77 \text { to } 4300 \text { heads } \\
3 \text { dairy: } 140 \text { to } 3500 \text { heads }\end{array}$ & Levrouw et al. (2007) \\
\hline
\end{tabular}

\footnotetext{
${ }^{3}$ This country with its ultraliberal economy has had two devaluations in the past thirty years, a serious health crisis (foot-and-mouth disease, the country being an exporter for $80 \%$ ) and climatic events (droughts, floods). It makes it possible to consider situations where uncertainties are more significant than in a European country and with fewer safety nets.
} 
Boxed text 1: The paths to last - Dairy farming in Ségala (Begon et al., submitted) (commun traits of the trajectories)

- Stay small, being technically efficient is the key (indicator : level of production per dairy cow) (Little modification of areas, fast specialisation at the beginning of trajectory, partner works outside or not).

- Stay small, the whole farm ressources management is the key. (Little modification of areas, fast specialisation at the beginning of trajectory, partner works outside).

- Get "big" in milk and to stay technically efficient(Enlargement(byagglomeration) of areas; increase in quotas, livestock; tendency to specialisation or towards the idea of dairy specialisation, (even if, at certain phases, there may be several agricultural activities).

- To have a large dairy herd but also another herbivorous activity that is a «buffer» in the event of a hard shock. (Enlargement or large at the beginning, several activities in parallel but milk dominating; technical ambition milk then «management concern »). The whole farm ressources management is another key.

- Diversified "businessman": to be big with several activities of equal importance.( "To make deals", not necessarily to do as well as possible, with several irons in the fire and each one significant).

- Diversified "on local opportunities», keeping flexibility in the production process (Small structures, attempts at diversification or gathering, flexibility in the management of the dairy herd, without much ambition as to the level of dairy production)

Boxed text 2 : The paths to last in bovine farms of Uruguay (Levrouw et al., 2007)

- Survival : diversification on local opportunities, daily adjustement of the farm management without medium - long term planning.

- Get "bigger" with a flexible - extensive - livestock management and without debts

- Invest into technologies in order to increase the livestok and land productivity

- Control maximum with a management planning, a prudent and calculated increasing of areas and investment into technologies

The paths have significant proximities in their content between Segala (France) and Uruguay and also Burgundy (see boxtext 3 ) even if "investments into technologies" or "technical efficiciency" or "get bigger" strategies have rather different realities in one place or another. Our resutls suggest that the factors fot paths differentation could be candidate to generalisation.

Each path generates tensions which influence the systems' resistance to uncertainties and on the way in which the farm receives injunctions to change (the market operators, CAP, environmental issues). In the following part we deal with the question of resistance to uncertainties, via the concept of flexibility.

\section{Exploring the operational flexibility of livestock systems}

Flexibility is a concept of management sciences and industrial economy. It goes back to the image "of the reed which bends but does not break" (Jean de La Fontaine, french poet). An abundant literature details the utility of this concept which seeks to take account of an essential property of a complex adaptive system subjected to disturbances. We report here two definitions of flexibility:
- - «Aptitude to adapt to circumstances, to absorb changes, an ability to preserve and create options, to learn» (Chia \& Marchenay, 2008). This definition opens onto the question of increase in sources of flexibility and learning.

- - «Procedures which make it possible to increase the capacity of control over the environment, to decrease the sensitivity of the system to its environment» (Astigarraga et al. , 2008). This definition leads us to consider the degree of pro-activity of the information-decision system to anticipate and react to the occurrence of hazards. These authors specify moreover that flexibility is a property which depends on the context (hazards taken into account) and on the goals sought.

- We are interested more particularly here in the study of the sources of operational flexibility, the flexibility that refers, in the agricultural context, to levers allowing a system to cope with variations in climate or price. Tarondeau (1999) identifies two families of sources: internal (relating to the production system) and external (linked to the socioeconomic networks). The internal sources are a range of inputs, processes and product flexibility (boxed text 2). 
Boxed text 2. The internal sources of flexibility: illustrations in herbivore farming (technical and work fields)

- Inputs: product specifications and revisable processes (for example: rules for adjusting the female destiny in beef cattle, the choice of weaning date, adjustment of the length of reproduction sessions; adjustment of the distribution of work and the content of tasks between the week and the weekend

- Processes with potentially useful resources, not too specialised (for example crops of cereals for selfconsumption on the farm or sold according to the state of stocks; a low stocking rate to limit the impact of climatic variations; preparation of tide-over pasture to cope with difficult periods (putting out to grass, waiting for the autumn rains) ; multiple skills of workers; stable forms of work organisation including at peak periods

- Diversity of products (types of animal products and sales periods)

- Studying operational flexibility thus makes it possible to compare the tensions and the principal sources of flexibility in the operation of livestock systems. In boxed text 3 we illustrate interactions between the typology of the paths to last in beef cattle farming in Burgundy (cf table 1) and the sources of internal and external flexibilities of farming systems (positive or negative = tensions). This boxed text clearly shows that sources and very variable levels of flexibility are associated with each type of system, without completely positive solutions. The highly intensive system with production of 18 months old young bulls, a priori very sensitive to climate and prices variations, has a real capacity to resist which comes from the fact that it is supported by a collective organisation (producers group) in the event of a hard shock. The highly autonomous system is a priori very resistant to climatic variations and price volatility. But the principle of autonomy does not apply only to the forage system. It causes fragility with respect to work, if one of the permanent workers is absent.

Boxed text 3: Operational flexibility of livestock systems in Burgundy, according to paths to last over the long term (Ingrand et al., 2007). The hazards considered: drop in price of cattle, drought. High tensions — ; High flexibility ++

Type 1 : Technical efficiency by optimisation + investment in the collective (downstream)

- Farm characteristics: production of 18 month old young bulls; high stocking rate (higher than 1.8 LU / ha main fodder area) ; early calvings; group sales; small areas

Tensions and flexibility: on single product and high stocking rate internal techical and economical tensions -; sales with the producers group, which helps in difficult periods (for example group purchases of forage during drought conditions) external technical - ecomical flexibility ++; small area for a couple of farmers work flexibility +.

Type 2 : Get bigger

Farm characteristics: large areas, production of store cattle, a little part of female being fattened depending on the year, medium stocking rate

Tensions and flexibilities : a dominant product but room for manœuvre on the female destiny (fattening or not), stocking rate : internal technical economical flexibility + . High work loads work tension -

Type 3 : Retain flexibility within the production system; keep autonomy
- Farm
characteristics:
low
stocking
rate

( $<1.2 \mathrm{LU} /$ ha), many private purchasers of animals, several animal products (store and fat cattle, more or less developed store calves), with variable distribution according to years. Medium to large size. Principle of autonomy in all respects.

- Tensions and flexibilities: low stocking rate, several products: internal technical and econimical flexibility ++ , several purchasers external technical - economical flexibility ++ ; very high autonomy in work work tension -

Type 4 : Diversify with other important activities

- Farm characteristics: the sizing of the cattle activity can vary; cattle products changing from one year to another, intermediate stocking rates and areas. Other agricultural (vineyard, crops) or non agricultural activities,

- Tensions and flexibilities: adjustment of products according to market prices and stores, stocking rate internal technicaleconomical flexibility + , competition between activities for work work tension - 


\section{Production process » (internal) flexibility}

While considering all the sources of a system's operational flexibility, technical research is interested more particularly in internal «production process» flexibility. Many works thus explore the "regulating properties" (Santucci 1991) of the operation of livestock systems in situations marked by hazards. These « regulations», a term of systemic vocabulary, express how interactions between elements of a system lead it to have an overall behaviour different from the sum of the behaviours of the individuals that compose it (Dedieu et al., 2008b). Fewer works take into account the work component of the "production process" flexibility, that can be notably evaluated by the room for manoeuvre in working times the farmer has (Dedieu et al. 1998) or by the stability of the work organization forms (labour distribution between daily - routine tasks and no daily - defferable tasks) (Madelrieux et al., 2009).

The regulation properties of the operation of livestock farming systems

Let us take a concrete example: what are the consequences of a $15 \%$ drop in the fertility level applied to each reproduction session for a flock of sheep managed in 3 lambings in 2 years? Does it eventually cause a much higher drop inannual numerical productivity of the flock, as one might expect taking into account the required reproduction rate (the ewes must reproduce every 8 months)? The answer as suggested by data-processing simulation is: no, the fall is $13-14 \%$, in any case under conditions where the flock management rules are those recommended by the INRA (systematic change of batch of infertile ewes, culling after the $3^{\text {rd }}$ reproduction failure) (Cournut \& Dedieu, 2004).

Generally speaking, the regulating properties of «controlled biological systems» such as the herd are based on two combined sets of phenomena:

- biological plasticities like the capacity of females to mobilize and reconstitute their body reserves and to arbitrate, in the short and medium term, between reproduction function and safeguard of integrity (Blanc et al., 2004),

- the organisation oflivestock production, i.e. a set of decisions about replacement/culling, and management of diversity: batching and management of these batches (reproduction, feed, marketing...) including movements of animals between batches in the event of need (Ingrand et al., 1993).

The complexity of the phenomena brought into play, their nature (decisional, biological) and the interactions make it necessary to turn to modelling i) to take account of the regulations concerned and ii) to estimate the implications on production of various combinations involving uncertainties and adjustment of management rules. To go back to the above example of drop in fertility applied to a flock of sheep, the phenomena concerned bring into play:

- increase in flows of infertile ewes passing from one reproduction batch to another. These flows modify (increase) the numbers presented to the rams at each mating session;

- increase in replacements (entries - exits) because of the culling rules for infertility. The rejuvenation of the demographic structure of the flock has a positive influence on the flock;

- the increase in the diversity of the productive trajectories (Tichit et al., 2004) with more trajectories of ewes that include episodes of infertility. These episodes are in the end favourable to prolificacy insofar as these ewes are less exhausted biologically by an accumulation of close gestations.

\section{Farmers room for manoeuvre in working times}

Researches have been developped in order to qualify and evaluate work organization in livestock farms with attention to the livestock production processes (Madelrieux \& Dedieu, 2008). With the "Bilan Travail" (Work Assesment) method, one can estimate the time remaining available for the farmer (= his room for manoeuvre in time) once his share of routine work (daily care of animals), seasonal work (herd or batches handling, forage system and crops activites) has been carried out and once he has returned the mutual aid received. Boxed text 4 gives an example of what explain two levels of work flexibility for two comparable farms : the combining of livestock and land management choices, equipement level and labor management. 
Boxed text 4 : Livestock farming system management, work organisation and room for manoeuvre (Calculated time available (hours/year). Illustration from two sheep farms in the region of Montmorillon (Vienne) (Dedieu et al., 1998)

Two large farms, both run by one farmer, the only permanent worker, with fairly similar flock management (predominantly winter lambing, with a few lambs born between November and December and production of grass lambs).

Farmer A has no crop cultivation, whilst farmer B grows cereals for his own animals' feeding. The equipment and buildings (old) represent very little capital compared to the value of the flock (less than 35\%). The current income of the two farms is excellent. On the other hand, farmer A's calculated time available is 500 hours greater than farmer B's, mainly because of the difference in need for bringing in outside labour for seasonal work.

\begin{tabular}{|lcc|}
\hline Farmer & A & B \\
Arable area (ha) & 176 & 140 \\
Herd (Livestock Unit) & 105 & 113 \\
Routine work (hours/year) & 1664 & 2312 \\
Seasonal work (days/year) & 110 & 98 \\
Work repaid (days/year) & 0 & 0 \\
Calculated time available (hours/year) & 1058 & 528 \\
\hline
\end{tabular}

Farmer A makes radical choices in terms of work organisation, by expressing the choice of one occupation and one alone: that of shepherd. It is in the very close monitoring of animals that his expertise is expressed, along with that of dog handler (routine work and seasonal flock work, and above all, sorting out lambs every week to present buyers with very homogeneous batches of lambs). The other tasks must not compete with this activity. Two types of work are delegated to labour from outside the base group: sheep-shearing, where volunteers and shearing contractors work together in large numbers to limit the shearing time ( 1 day), and seasonal work on the forage land (roller chopping, hay press and grass sowing one year in three) largely carried out by volunteer workers (children on school holidays) and contractors.

Farmer B sees his job as being that of a shepherd associated with that of a grower of grass (temporary meadows) and cereals (for feeding). Bringing in labour from outside the base group is reduced to large tasks where it is absolutely necessary (shearing, round bail silage and harvesting). Here it involves work organisation based on mutual help, which in return requires repaid work. "But mutual help is also a chance for colleagues to exchange news and information".

\section{Conclusions}

Increasing uncertainty about conditions in the future and the search for systems which «make do with» the uncertainties rather than seek to smooth them out, implies giving great attention to the adaptive capacities of livestock farming systems. And, as a consequence, to time scales (medium and long term) which make it possible to take into account the disturbances to which they are subjected. The researches presented here does not claim to cover the vast field of research on the adaptation of livestock farming systems or to propose turn-key results that can be used as they are within the framework of advice. However this paper wants to testify to a main line of work which is tending to be developed in France and Europe, whereas most research on systems in situations of uncertainty used to be based on case studies in countries of the South which had neither a moderate climate, nor a protective Common Agricultural Policy.
In the end, resistance to uncertainties and shocks, the aptitude to seize new opportunities to reconfigure a system is based on simple statements (Darnhofer et al., 2008):

- To preserve and renew the diversity of activities, resources, productive animal trajectories... and of social standards of what is the appropriate "livestock management" and what is the appropriate "farming style" (Van der Ploeg 1990)

- To seek multi-sources flexibility (internal and external)

- To develop a capacity for learning, enabling the accumulation and mobilization of past experiences at the service of decisions for the future.

\section{Literature Cited}

ASTIGARRAGA, L.; CHIA, E.; INGRAND, S. Production flexibility in extensive beef farming systems in the Limousin region. In: EUROPEAN IFSA SYMPOSIUM: empowerment of the rural actors: a renewal of farming systems perspectives, 8., 2008, 
Clermont Fd (France). Proceedings... Clermont Fd, 2008. p.385-402.

BLANC, F.; BOCQUIER, F.; DEBUS, N. et al. La pérennité et la durabilité des élevages de ruminants dépendant des capacités adaptatives des femelles. Inra Productions Animales, v.17, n.4, p.287-302, 2004.

CHIA, E.; MARCHENAY, M. Un regard des sciences de gestions sur la flexibilité : enjeux et perspectives. In: DEDIEU, B. et al. (Eds.) L'élevage en mouvement: flexibilité et adaptation des exploitations d'herbivores. Ed. Quae, 2008. p.23-36.

COURNUT, S.; DEDIEU, B. A discrete event simulation of flock dynamics: a management application to three lambings in two years. Animal Research, v.53, p.383-403, 2004.

CYRULNICK, B. Les vilains petits canards. Paris: Odile Jacob, 2001.

DARNHOFER, I.; BELLON, S.; DEDIEU, B. et al. Adaptive farming systems: a position paper. In:EUROPEAN IFSA SYMPOSIUM: empowerment of the rural actors: a renewal of farming systems perspectives, 8., 2008, Clermont Fd (France). Proceedings... Clermont Fd, 2008. p.339-351.

DEDIEU, B.; CHABOSSEAU, J.M.; WILlAERT, J. et al. L'organisation du travail dans les exploitations d'élevage : une méthode de caractérisation en élevage ovin du Centre-Ouest. Etudes et Recherches sur les Systèmes Agraires et le Développement, v.31, p.63-80, 1998.

DEDIEU, B.; CHIA, E.; LECLERC, B. et al. L'élevage en mouvement: flexibilité et adaptation des exploitations d'herbivores. Ed. Quae, Collection Sciences\&Technologie Update, 2008a. 294p.

DEDIEU, B.; FAVERDIN, P.; DOURMAD, J.Y. et al. Système d'élevage, un concept pour raisonner les transformations de l'élevage. INRA Prod. Animal, v.21, n.1, p.45-58, 2008b.

DEDIEU, B.; ZASSER-BEDOYA, S. In: EUROPEAN IFSA SYMPOSIUM: empowerment of the rural actors: a renewal of farming systems perspectives, 8., 2008, Clermont Fd (France). Proceedings... Clermont Fd, 2008. (CD-ROM).

GIBON, A.; HERMANSEN, J.E. Sustainability concept in Livestock farming system research orientations. EAAP 2006, Antalya, Turkey - Session 1 Ethics of sustainability (invited paper). 2006

HOLLING, C.S. Understanding the complexity of economic, ecological, and social systems. Ecosystems, v.4, p.390-405, 2001.

INGRAND, S.; BARDEY, H.; BROSSIER, J. et al. Flexibility of suckler cattle farms in the face of uncerntainty within beef industry: a proposed definition and an illustration. Journal of Agricultural Education and Extension, v.13, n.1, p.39-48, 2007.
INGRAND, S.; DEDIEU, B.; CHASSAING, C. et al. Etude des pratiques d'allotement dans les exploitations d'élevage. Proposition d'une méthode et illustration en élevage bovin extensif Limousin. INRA Et. Rech. Syst. Agr. Dev. , v. 27, p.5272, 1993.

LEV L., CAMPBELL D. The temporal dimension in Farming sytems research : the importance of maintaining flexibility under conditions of incertainties. Journal of Rural Studies, v.3, n.2, p.123-132, 1987.

LEMERY, B.; INGRAND, S.; DEDIEU, B. et al. "Agir en situation d'incertitude : le cas des éleveurs bovins allaitants." Economie Rurale, v.288, p.57-69, 2005.

LEVROUW, F.; MORALES, H.; ARBELETCHE, P. et al. Estrategias de largo plazo de los ganaderos uruguayos en situationces de incertitumbre. Agrociencia, v.11, n.2, p.87-93, 2007.

MADELRIEUX, S., DEDIEU, B. Qualification and assessment of work organisation in livestock farms. Animal, v.2, n.3, p.435447, 2008.

MADELRIEUX, S., DEDIEU, B., DOBREMEZ, L. et al. Patterns of work organisation in livestock farms: the ATELAGE approach. Livestock Science, v.121, p.28-37, 2009.

MIGNON, S. Stratégie de pérennité d'entreprise. Paris: Vuilbert, 2001.

MILESTAD, R., DARNHOFER, I. 2003. Building farm resilience: the prospects and challenges of organic farming. Journal of Sustainable Agriculture 22(3) : 81-97.

MOULIN, C.H.; INGRAND, S.; LASSEUR, J. et al. Comprendre et analyser les changements d'organisation et de conduite de l'élevage dans un ensemble d'exploitations: propositions méthodologiques. In: DEDIEU, B. et al. (Eds) L'élevage en mouvement: flexibilité et adaptation des exploitations d'herbivores. Ed. Quae, 2008. p.181-196.

Santucci, P.M. Le troupeau et ses propriétés régulatrices, bases de l'élevage extensif. Thèse de doctorat Université Montpellier II, 1991. 85p.

Tarondeau, J.C. La flexibilité dans les entreprises. Que sais-je ? PUF, 1999. 126p.

TICHIT, M.; INGRAND, S.; MOULIN, C.H. et al. Analyser la diversité des trajectoires productives des femelles reproductrices: intérêts pour modéliser le fonctionnement du troupeau en élevage allaitant. Inra Prod. Animal, v.17, n.2, p.123-132, 2004.

Van der PLOEG, J.D. Styles of farming. An introductory note on concepts and methodology. In: VAN DER PLOEG J.D.; LONG, A. (Eds.) Born from within. Pratices and perspectives of endogenous rural developement. Assen/Maastricht, NL:Van Gorcum, 1990. p.7-30. 